\title{
A Study on Ranking Key Factors of Virtual Teams Effectiveness in Saudi Arabian Petrochemical Companies
}

\author{
Abdullah Basiouni \\ Department of Management Sciences \\ and Industrial Management \\ Technology \\ Yanbu University College \\ Yanbu Industrial City, Saudi Arabia \\ Walid Bahamdan \\ Sara Holding \\ Riyadh, Saudi Arabia
}

\author{
Kang Mun Arturo Tan \\ Department of Management Sciences \\ and Industrial Management \\ Technology \\ Yanbu University College \\ Yanbu Industrial City, Saudi Arabia
}

\author{
Hafizi Muhamad Ali \\ Department of Management Sciences \\ and Industrial Management \\ Technology \\ Yanbu University College \\ Yanbu Industrial City, Saudi Arabia
}

\begin{abstract}
This research ranks effectiveness-related factors of virtual teams. The literature suggests various factors which could motivate or discourage management in using virtual teams versus co-located teams. Forty-eight interviews were done in petrochemical companies in Saudi Arabia. The Echo Method has been employed and eleven factors were identified. Results showed that the participants ranked efficiency and communication as first and second as a motivating factor in adopting the virtual team approach. While, the other three motivating factors which were ranked lower are flexibility, diversity and cooperation. On the other hand, the six discouraging factors (barrier) are miscommunication, scheduling preferences, unreliability of technology, incompetency of staff, varying standards and isolationist tendency. Suggestions were made to counteract the effects of the barrier-inducing factors and enhance the effects of the motivating factors.
\end{abstract}

Keywords-Virtual teams; Social network; Echo method; Quantitative analysis

\section{INTRODUCTION}

The drive towards speed, cost rationalization, quality of output and broad reach for dispersed market encourages organizations to consider virtual teams as an approach to organizing tasks and delivering result [32].

This paper examines the literature on this issue and performed a validation using social network survey research in identifying key factors which make virtual team deliver its promises.

The unique contribution of this work is the attempt to rank various factors as to why management would use virtual teams. Ranking the factors affecting the adoption of virtual teams is important so that the management could utilize more fully the driving factors and avoid (or use counteracting solutions) the discouraging factors.

These factors are deeply imbedded into the subconscious of the staff that one of the best ways of eliciting these factors is the use of Echo Method. Through the Echo Method, those staff was able to communicate their inner thoughts to the interviewer [25].

The driving factors (motivator), in terms of ranking, are: efficiency, communication, flexibility of work place and time, diverse skill sets and cooperative attitudes. The discouraging factors (barrier), in terms of ranking are: miscommunication, scheduling preferences, unreliability of technology, staff incompetence, varying standards and isolationist attitudes.

This paper suggests that in any undertaking utilizing the virtual team approach, the management should ensure that each member have a superior written communication skills and a tight work contract. Further, the management should have the latest update of information and communication technology infrastructures. Moreover, work procedures and decision rights should be properly documented and disseminated to all members and stakeholders.

The above-stated result of this paper is significant. By working on the inner thoughts elicited through the Echo Method, ranking them, and coupled with what are already discussed in the literature, this paper suggests a water-tight process of working with virtual teams.

This paper is organized by presenting the literature review and followed by a description of the research methodology. The results of the study are then presented and discussed, together with highlighting the conclusions and managerial recommendations.

\section{LITERATURE REVIEW}

The literature is filled with various aspects about virtual teams. In this review, we present the current thinking about what it is, why people resorts to the use of virtual teams, what are its benefits and drawbacks. 
Based on various papers, virtual teams come about when a common goal is attained by different individuals working from different time zone, place and organization and coordinated by information and communication technologies [1,4,6-9,12,19-20,22-23,26,30]. Having cited these authors, it leaves us to explore the idea that virtual teams are communicating purely or partially through remote-based communication technologies? Martins, Gilson and Maynard stated that it is not necessarily either virtual or face-to-face. It could be a proportion of face-to-face communication or remote, technology-based communication. In fact, the use of remote related technologies depends on several factors: (i) the nature of the task, (ii) the technological resources at the team's disposal, and (iii) the team members' diverse background [21].

The idea that the team members are coming from different places, time zones and geographical areas suggests the issue of diversity (cultural, skills and language). It has been noted that as a natural consequence of team members' diversity, communication - the main means of human coordination, is heavily affected. Shachaf et. al. [29] has noted that communication among global virtual team members is more complex due to the fact that it is mediated by computers and involves cross-cultural communication. Hence, effective communication has become a critical factor for success in the virtual setting.

Amidst this characterization of virtual teams, more and more organizations have used virtual team approach as a means of managing any form of undertaking, short-term as in a project, or operational, as in call-centers. Efficiency has become one of the main drivers for using virtual teams. For example, the use of virtual teams significantly reduce the time and costs incurred in travel [5,9]. This finding has been reinforced by Ale Ebrahim who noted that within Malaysian manufacturing Small and Medium Enterprises (SMEs), virtual teams reduced research and development $(R \& D)$ costs and time [1].

The literature further indicates that the use of virtual team reduces the cost of accommodating employees. Virtual team approach translates into less traveling as the employees are working from home. This translates into less office and parking space and in the end the company reduces its real estate expenses [3,24].

Aside from the economic impact, the diversity factor of virtual teams brings in a lot of benefit to the company. The dimension of virtual team gives the company wider skill set, broader cultural understanding and bigger recruitment base for talents $[21,1,5,13]$.

Flexibility has likewise resulted from virtual teams. The ability to work beyond time, organizational constraints and locations, enhances the competitive agility of organizations $[21,26]$. Further cross-territorial communication is attained by virtual teams. Since the individuals are coming from different areas, information from those areas are readily available for the virtual team $[15,31]$.

While working towards a goal, the use of information and communication technologies (ICTs) form the backbone of the virtual team concept. The ICT is what makes it virtual. Email, collaborative software, video conferencing, phone and mobile devices form the basic technology support [15]. Martins [21] have asserted that the technology set used by the virtual team has a direct impact on the team's efficiency, commitment, and amount of communication and relationships among the team members. Jarvenpaa and Maznevski asserted that a mix of face-to-face interactions and ICT-based interactions is possible [14,22].

The permanency issue of the virtual team has been explored by various researchers $[10,18,30]$. A team who has a long-term possibility of staying together tend to perform better than a team who is there for a short time.

One key point that leads to an individual to work for the team is trust. Luo $\mathrm{Lu}$ [17] found that a member's trust is built if he perceives a similarity of values, attitudes and beliefs with the rest of the team. Another factor is benevolence: that is the team member believes that the other team members would like to do good to him [17].

While trust leads to an effort to work for the team, there are other factors that lead to positive knowledge sharing attitude. Killingsworth et. al noted that trust, reciprocal benefits, enjoyment and computer experience contributes to a positive knowledge sharing attitude [16].

Derven [11] identified four factors that lead to virtual team effectiveness. These are diversity and inclusion, purpose, people and processes. Derven asserted that a right mix of people should be attained in terms of gender, age, race, ethnicity, cultural background, education, sexual identity, orientation, values, thinking styles and others. Further, purpose should be clearly specified. People should be recruited based on requirements, relationships should we specified, and rewards and recognition should be made at an appropriate time. Finally, a formal process of governance and working together should be documented [11].

Summarizing, the literature presents virtual teams as a group of individuals who work together towards a common purpose. Interacting through the use of information and computer technology, they work across different time zones, different places, and organizational boundaries. The virtual team might exist permanently or for a short duration. As a result of having different people of diverse backgrounds in a group, the virtual team attains significant gains in terms of efficiency, broad collection of skills, flexibility, and other capabilities. The choice of technology set affects how the team coordinates with one another. On the other hand, the virtual teams could experience multiple challenges such as miscommunications and doubts regarding ones real agenda. Issues of doubts about one another should be addressed. Trust could be enhanced by team members having similar values, attitudes and beliefs. Aside from trust, reciprocal benefits, enjoyment, and computer experience positively affects work attitudes. Further, a well specified purpose, relationships and remunerations, and work processes enhance global virtual teams. 


\section{RESEARCH METHOD}

This study tries to identify factors that helps in the adoption of virtual team approach and which factor hinders such adoption. The management has an option of putting all staff on day one in one huge office or allow the staff to work from dispersed places. Results of this study will be useful for managers who are accountable for the attainment of result within budget.

In order to identify those factors, this study looked at the inner psychology of members of previous team members. The Echo Method reveals the interviewees' perspectives, views, and thoughts, which in turn "echo" the interviewees' unique values and beliefs with minimal research interference [25].

The first part of Echo Method involves collecting general background information about the interviewee's current job, daily tasks/activities and role, and years of experience in the current position. The second part involves a network diagram as shown in Figure 1. The central node represents the interviewee, and the other connected nodes represent those with whom the interviewee interacts as part of the virtual team, which can include individuals (e.g., team leader), groups (e.g., team members), and technologies (e.g., virtual team technology).

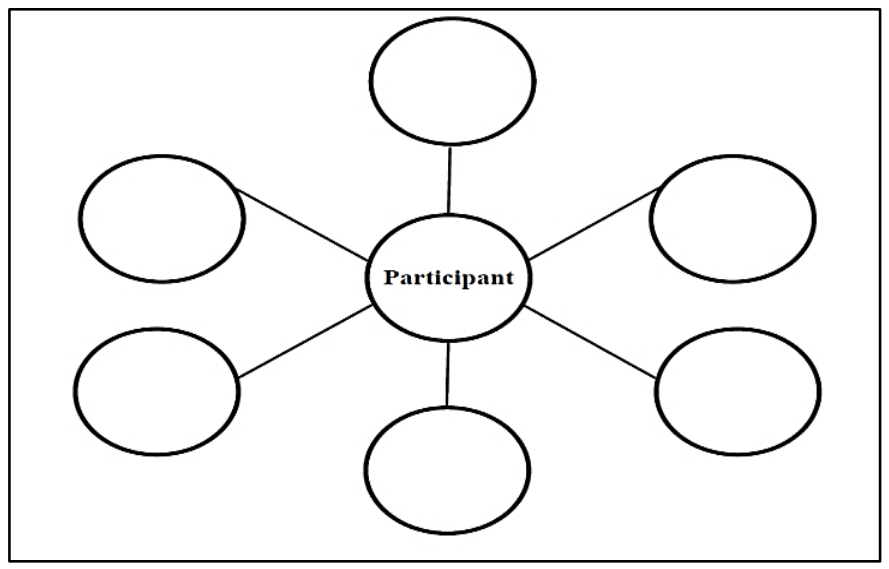

Fig. 1. Blank Social Network Diagram

In this second part, the interviewee is asked to identify behavioral examples with those nodes, for example, emailing. For such behavior, the interviewee is asked to code it as "helpful" (motivator) or "not-so-helpful" (barrier) in terms of attaining virtual team tasks. Forty eight interviews with staff working in maintaining high-technology materials and equipment were done in petrochemical companies in Saudi Arabia.

\section{RESULTS AND ANALYSIS}

After the 48 interviews were conducted based on the Echo Method, all interviews were transcribed. The text was systematically coded into two groups: examples of helpful behaviors (motivator) and examples of not-so-helpful behaviors (barrier). The first step of the analysis was performed using frequency by counting the number of behaviors in each of the two categories, as shown in Figure 2. Examples of helpful behaviors would be different skills/knowledge brought to the tasks while not-so-helpful behaviors would have loss of social contact (for example, handshakes) as its example.

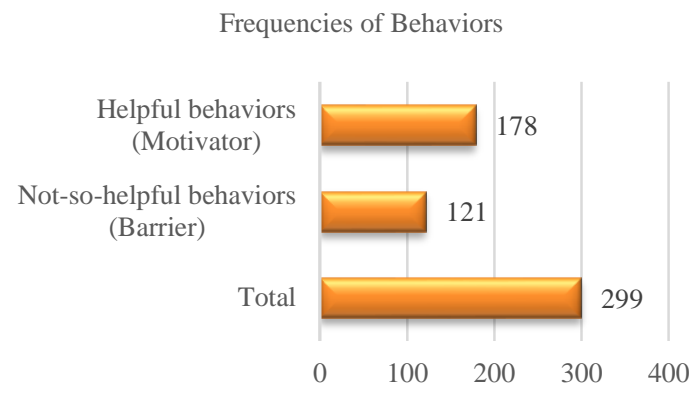

Fig. 2. Frequencies of Behaviors

\section{A. Perceived Interaction Effectiveness Ratio (IE)}

An indicator of the relative effectiveness of employing virtual teams is called the perceived interaction effectiveness ratio (IE). The IE is calculated as the ratio between the numbers of helpful statements (motivator) to the number of not-so-helpful statements (barrier) [27]. This study yielded the IE ratio to be 1.48 , meaning there is 1.48 helpful statements (motivator) for every 1 not-so-helpful statement (barrier).

\section{B. Categorical Analysis}

In this second step, three independent researchers analyzed the responses for over a period of two months. The analysis was iterative, and after a consensus is attained by the three researchers, the factors were identified.

In this study, the researchers classified the helpful examples (motivator) into five different factors, namely: efficiency, communication, flexibility, diversity and cooperation. On the other hand, the not-so-helpful factors (barrier) were categorized into six factors, namely: miscommunication, scheduling preferences, unreliability of technology, incompetence of staff, varying work standards, and isolationist tendencies. 
TABLE. I. DISTRIBUTION OF HELPFUl EXAMPLES (MOTIVATOR)

\begin{tabular}{|c|c|c|c|}
\hline Factors & $\begin{array}{l}\text { \# of } \\
\text { Examples }\end{array}$ & $\begin{array}{l}\text { Working } \\
\text { Definition }\end{array}$ & Typical Example \\
\hline \multicolumn{4}{|c|}{$\begin{array}{l}\text { Helpful Behaviors } \\
\text { (Motivator) }\end{array}$} \\
\hline Efficiency & $\begin{array}{l}(30.9 \%) \\
(55)\end{array}$ & $\begin{array}{l}\text { The extent to } \\
\text { which time, } \\
\text { effort, or cost } \\
\text { is well used } \\
\text { for the } \\
\text { intended task } \\
\text { or purpose }\end{array}$ & $\begin{array}{l}\text { Expedited decision } \\
\text { making due to easy } \\
\text { and quick ways to } \\
\text { gather all } \\
\text { stakeholders for a } \\
\text { short meeting }\end{array}$ \\
\hline Communication & $\begin{array}{l}(23.6 \%) \\
(42)\end{array}$ & $\begin{array}{l}\text { The transfer } \\
\text { of } \\
\text { information } \\
\text { from one } \\
\text { unit to } \\
\text { another }\end{array}$ & $\begin{array}{l}\text { Easy way to share } \\
\text { information/updates, } \\
\text { "all members on the } \\
\text { same page" }\end{array}$ \\
\hline Flexibility & $\begin{array}{l}(21.9 \%) \\
(39)\end{array}$ & $\begin{array}{l}\text { The freedom } \\
\text { to choose the } \\
\text { time and } \\
\text { place for } \\
\text { work }\end{array}$ & $\begin{array}{l}\text { Centralized time } \\
\text { zone allows for } \\
\text { working with both } \\
\text { east and west during } \\
\text { working hours }\end{array}$ \\
\hline Diversity & $\begin{array}{l}(14.6 \%) \\
(26)\end{array}$ & $\begin{array}{l}\text { The variety } \\
\text { of } \\
\text { experiences } \\
\text { and } \\
\text { perspectives } \\
\text { that arise } \\
\text { from } \\
\text { differences } \\
\text { among } \\
\text { members, } \\
\text { governments, } \\
\text { countries, } \\
\text { etc. }\end{array}$ & $\begin{array}{l}\text { Different skills and } \\
\text { knowledge are } \\
\text { brought into the } \\
\text { tasks }\end{array}$ \\
\hline Cooperation & $\begin{array}{l}(9 \%) \\
(16)\end{array}$ & $\begin{array}{l}\text { The degree } \\
\text { of } \\
\text { willingness } \\
\text { to help }\end{array}$ & $\begin{array}{l}\text { Following up and } \\
\text { coordinating with } \\
\text { customers when one } \\
\text { person is busy, } \\
\text { "good backup" }\end{array}$ \\
\hline Total & $\begin{array}{l}(100 \%) \\
(178)\end{array}$ & & \\
\hline
\end{tabular}

Efficiency is the highest ranking factor on the helpful side, accounting for $30.9 \%$ of the total number of helpful examples. It is followed by communication, which represents $23.6 \%$ of the helpful examples. Thus, together, efficiency and communication examples dominate the area of helpful factors. Flexibility, with a proportion of $21.9 \%$, is seen as another favorable outcome of the virtual teams. Diversity, with $14.6 \%$, is also perceived as a favorable outcome, albeit to a lesser degree. Cooperation received the lowest number of responses, comprising only $9 \%$ of the helpful examples. These results are represented across the different factors in Table 1.

In terms of the not-so-helpful (barrier) factors, statements were classified into six factors. Table 2 shows the emerging factors, along with their frequencies, working definitions, and concrete examples.
TABLE. II. DISTRIBUTION OF NOT-SO-HELPFUL EXAMPLES (BARRIER)

\begin{tabular}{|c|c|c|c|}
\hline Factors & $\begin{array}{l}\text { \# of } \\
\text { Examples }\end{array}$ & $\begin{array}{l}\text { Working } \\
\text { Definition }\end{array}$ & Typical Example \\
\hline \multicolumn{4}{|c|}{$\begin{array}{l}\text { No-so-helpful Behaviors } \\
\text { (Barrier) }\end{array}$} \\
\hline Miscommunication & $\begin{array}{l}(36.4 \%) \\
(44)\end{array}$ & $\begin{array}{l}\text { Cases in which } \\
\text { information was } \\
\text { not transformed as } \\
\text { desired }\end{array}$ & $\begin{array}{l}\text { Accent issues and } \\
\text { weaknesses in the } \\
\text { English language } \\
\text { itself }\end{array}$ \\
\hline $\begin{array}{l}\text { Scheduling } \\
\text { Preferences }\end{array}$ & $\begin{array}{l}(21.5 \%) \\
(26)\end{array}$ & $\begin{array}{l}\text { Difficulties arising } \\
\text { out of the } \\
\text { technology (e.g., in } \\
\text { choosing time and } \\
\text { place) and the } \\
\text { social norms } \\
\text { established around } \\
\text { its use (e.g., } \\
\text { behavioral norms } \\
\text { in a particular } \\
\text { culture to which } \\
\text { individuals are } \\
\text { expected to } \\
\text { conform). }\end{array}$ & $\begin{array}{l}\text { Communication } \\
\text { gaps created by } \\
\text { the difference in } \\
\text { time and the } \\
\text { nature of virtual } \\
\text { teams as to the } \\
\text { actual timing of } \\
\text { work days and } \\
\text { weekends }\end{array}$ \\
\hline $\begin{array}{l}\text { Unreliability of } \\
\text { technology }\end{array}$ & $\begin{array}{l}12.4 \% \\
(15)\end{array}$ & $\begin{array}{l}\text { The instability of } \\
\text { the technology in } \\
\text { facilitating virtual } \\
\text { teamwork }\end{array}$ & $\begin{array}{l}\text { Frequent outages } \\
\text { in IT services }\end{array}$ \\
\hline $\begin{array}{l}\text { Incompetency of } \\
\text { staff }\end{array}$ & $\begin{array}{l}11.6 \% \\
(14)\end{array}$ & $\begin{array}{l}\text { The lack of a } \\
\text { normally expected } \\
\text { degree of ability }\end{array}$ & $\begin{array}{l}\text { Technical "know- } \\
\text { how" difficulties; } \\
\text { "not doing a good } \\
\text { job or not doing } \\
\text { what they are } \\
\text { supposed to do" }\end{array}$ \\
\hline Varying standards & $\begin{array}{l}(9.1 \%) \\
(11)\end{array}$ & $\begin{array}{l}\text { The variety of } \\
\text { experiences and } \\
\text { perspectives that } \\
\text { arise from } \\
\text { differences among } \\
\text { members }\end{array}$ & $\begin{array}{l}\text { Age gaps between } \\
\text { virtual team } \\
\text { members; having } \\
\text { different } \\
\text { measureable } \\
\text { standards than } \\
\text { other countries } \\
\end{array}$ \\
\hline $\begin{array}{l}\text { Isolationist } \\
\text { Tendency }\end{array}$ & $\begin{array}{l}9.1 \% \\
(11)\end{array}$ & $\begin{array}{l}\text { A degree of } \\
\text { unwillingness to } \\
\text { help }\end{array}$ & $\begin{array}{l}\text { Resolving } \\
\text { problems among } \\
\text { team members is } \\
\text { very hard; } \\
\text { difficulty in } \\
\text { supervision } \\
\end{array}$ \\
\hline Total & $\begin{array}{l}(100 \%) \\
(121)\end{array}$ & & \\
\hline
\end{tabular}

As illustrated in Table 2, miscommunication is found to be the highest ranking factor, accounting for $36.4 \%$ of the not-sohelpful examples. In other words, communication issues tend to be a major issue in virtual teams. The second most prominent factor is scheduling preferences, which represents $21.5 \%$. This factor reflects the complications and nuisances faced by the members owing to the inherent rigidity of the virtual team setting and the awkward social norms that develop around this setting. Unreliability of technology is the third largest factor, constituting $12.4 \%$ of the not-so-helpful examples. It refers to the typical unpredictability and 
unreliability associated with technology. In contrast, isolationist tendency is the least noticeable category, representing $9.1 \%$ of the total not-so-helpful responses.

\section{DISCUSSION}

This section discusses the perceived interaction effectiveness ratio, as well as motivators and barriers to the implementation of virtual teams.

\section{A. Perceived Interaction Effectiveness Ratio (IE)}

The interaction effectiveness (IE) ratio was used to identify the perception of virtual team effectiveness based on concrete examples of helpful (motivator) and not-so-helpful (barrier) behaviors from a task-related social networking perspective. The IE ratio was found to be above 1 (1.47), which indicates that the virtual team environment is producing more helpful than not-so-helpful behaviors. This indicates that the virtual team approach is useful but not a panacea.

\section{B. Virtual Team Motivators}

Based on the data gathered, efficiency $(31 \%)$ is the strongest driver of why management chooses to use the virtual team approach. This is probably due to the ease of communicating (24\%) and flexibility of identifying work place and work schedule (22\%). Since most undertakings have a specific target and goal, diversity came fourth $(15 \%)$. It would be a different case if the goal is vague, and, therefore, a large set of knowledge is needed to be ready for deployment. Finally, cooperation came last (9\%). Since members of the team needed to generate their work based on a particular work assignment, cooperation is rarely an issue.

The second driving force in the adoption of virtual team is communication (23.6\%). There is a general appreciation for the use of virtual teams as ease of communication generally leads to overall efficiency. This finding is consistent with previous studies on communication within virtual teams $[24,29]$.

The third ranking factor is the flexibility of work place and schedule. This accounts for $21.9 \%$ of the total helpful examples. This finding is consistent with former studies $[10,13,21]$.

The fourth ranking factor is the diversity of skill sets. This was mentioned $15 \%$ of the responses. As the organizational goals are normally well-written out, there is no need to have on broad set of knowledge possessed by different people.

Finally, the last ranking factor is cooperation. This was mentioned $9 \%$ only. This might be due to the fact that many of the work contracts are well specified and therefore, there is no need for each team members to cooperate and give in during decision making.

\section{Virtual Team Barriers}

On the other hand, various discouraging factors (barrier) exist. At the top of the list is miscommunication, particularly verbal communication. This was mentioned $36.4 \%$ of the example statements. Many of the responses were identifying the lack of body language and hard-to-understand accents.
The second ranked discouraging factor (barrier) is scheduling preferences, which stood at $21.5 \%$. Due to the different time zones, many of the team members would want to meet-on-line at their convenience.

The third ranked discouraging factor (barrier) is unreliable technology which was mentioned at $12.4 \%$. This is brought about by financial constraints in most situations, but also caused by lack of knowledge of what type of technology is possible.

The fourth discouraging factor (barrier) is staff incompetence, which was mentioned $17 \%$ of the time. This is attributed to the loose recruitment requirements specification. Upon recruitment, specific work output has to be specified, and specific brand of technology also has to be known.

The fifth discouraging factor (barrier) is varying standards, which was mentioned at $9.1 \%$. People with diverse cultural and educational background have different notion of what is normal. This too could be due to loose requirements specification.

The last, isolationist tendency is calculated at $9.1 \%$. This is the least discouraging factor (barrier) as there are only few moments where a team member is asked to get out of his area of work to help out on a specific issue.

\section{CONCLUSION AND RECOMMENDATIONS}

This study has shown the rankings of various factors as to why the decision makers in an organization would opt for virtual team as a management approach. This is even reinforced by the greater than one interaction effectiveness (IE) ratio, indicating that virtual team carries so much promise.

Given a macro view of the results, and the corresponding review of literature, it shows that efficiency, doing more with less, is the primary driving force in adopting virtual teams. However, communicating with one another seems to be both a driving force as it is a discouraging factor (barrier). In order for this recommendation to be universal, it is recommended that written communication skills among team members be favored over verbal communication skills. In fact, if it is possible, form-based work-flows be used to coordinate various team members.

Moreover, due to the wide source of talents and skills, it is necessary to have a specific and tighter work contract be written out for each team member, including sample of work. In this case, each team member is fully aware of what is expected from him in terms of level of quality, quantity and turn-around time. Further, work procedures and decision rights should be properly spelt out and disseminated among team members and stakeholders. In this case, work responsibility is fully addressed.

Finally, the information and communication technology infrastructure should be properly updated. As much as possible, its fullest potential should be disseminated to the team members, and all team members should be using the full features of the technology deployed. 


\section{ACKNOWLEDGMENT}

The authors would like to acknowledge King Fahad University of Petroleum and Minerals for its support.

\section{REFERENCES}

[1] N. A. Ebrahim, S. Ahmed, and Z. Taha, "Virtual R\&D teams in small and medium enterprises: A literature review", Scientific Research and Essays, vol. 4(13), pp. 1575-1590, 2009a.

[2] N. A. Ebrahim, S. Ahmed, and Z. Taha, "Virtual teams: A literature review", Australian Journal of Basic and Applied Sciences, vol. 3(3), pp. 2653-2669, 2009b.

[3] R. Baskerville and J. Nandhakumar, "Activating and perpetuating virtual teams: Now that we're mobile, where do we go?", Professional Communication, IEEE Transactions On, vol. 50(1), pp. 17-34, 2007.

[4] B. S. Bell, and S.W. Kozlowski, "A typology of virtual teams implications for effective leadership", Group \& Organization Management, vol. 27(1), pp. 14-49, 2002.

[5] B. J. Bergiel, E. B. Bergiel, and P.W. Balsmeier, "Nature of virtual teams: A summary of their advantages and disadvantages", Management Research News, vol. 31(2), pp. 99-110, 2008.

[6] K.S. Bouas, and H. Arrow, "The development of group identity in computer and face-to-face groups with membership change", Computer Supported Cooperative Work (CSCW), vol. 4(2-3), pp. 153-178, 1995.

[7] W. F. Cascio, "Managing a virtual workplace", The Academy of Management Executive, vol. 14(3), pp. 81-90, 2000.

[8] N. Chase, "Learning to lead a virtual team", Quality, vol. 38(9), pp. 76$85,1999$.

[9] S. G. Cohen, and D. E. Bailey, "What makes teams work: Group effectiveness research from the shop floor to the executive suite", Journal of Management, vol. 23(3), pp. 239-290, 1997.

[10] P. L. Curseu, R. Schalk, and I. Wessel, "How do virtual teams process information? A literature review and implications for management", Journal of Managerial Psychology, vol. 23(6), pp. 628-652, 2008.

[11] M. Derven, "Four drivers to enhance global virtual teams", Industrial and Commercial Training, vol. 48(1), pp. 1-8, 2016.

[12] J. E. Driskell, P. H. Radtke, and E. Salas, "Virtual teams: Effects of technological mediation on team performance", Group Dynamics: Theory, Research, and Practice, vol. 7(4), pp. 297, 2003.

[13] F. M. Horwitz, D. Bravington, and U. Silvis, "The promise of virtual teams: Identifying key factors in effectiveness and failure", Journal of European Industrial Training, vol. 30(6), pp. 472-494, 2006.

[14] S. L. Jarvenpaa, K. Knoll, and D. E. Leidner, "Is anybody out there? Antecedents of trust in global virtual teams", Journal of Management Information Systems, vol. 14(4), pp. 29-64, 1998.

[15] P. Johnson, V. Heimann, and K. O'Neill, "The "wonderland" of virtual teams" Journal of Workplace Learning, vol. 13(1), pp. 24-30, 2001.
[16] B. Killingsworth, X. Yajiong, L. Yongjun, "Factors influencing knowledge sharing among global virtual teams", Team Performance Management, vol. 22(5/6), pp. 284-300, 2016.

[17] L. Lu, "Building trust and cohesion in virtual teams: the developmental approach", Journal of Organizational Effectiveness: People and Performance, vol. 2(1), pp. 55-72, 2015.

[18] L. Lee-Kelley and T. Sankey, "Global virtual teams for value creation and project success: A case study", International Journal of Project Management, vol. 26(1), pp. 51-62, 2008.

[19] J. Lipnack, "Virtual teams: Reaching across space, time, and organizations with technology", New York: Jeffrey Stamps, 1997.

[20] J. Lipnack, and J. Stamps, "Virtual teams: People working across boundaries with technology", Washington: John Wiley \& Sons, 2008.

[21] L. L. Martins, L. L. Gilson, and M. T. Maynard, "Virtual teams: What do we know and where do we go from here?", Journal of Management, vol. 30(6), pp. 805-835, 2004.

[22] M. L. Maznevski, and K. M. Chudoba, "Bridging space over time: Global virtual team dynamics and effectiveness", Organization Science, vol. 11(5), pp. 473-492, 2000.

[23] M. M. Montoya-Weiss, A. P. Massey, and M. Song, "Getting it together: Temporal coordination and conflict management in global virtual teams", Academy of Management Journal, vol. 44(6), pp. 1251-1262, 2001.

[24] R. Nydegger, and L. Nydegger, "Challenges in managing virtual teams", Journal of Business \& Economics Research, vol. 8(3), 2010.

[25] C. Poile, "The echo method: Investigating socio-technical interactions", Socio-Technical Congruence Workshop, 2008.

[26] A. Powell, G. Piccoli, and B. Ives, "Virtual teams: A review of current literature and directions for future research", ACM Sigmis Database, vol. 35(1), pp. 6-36, 2004.

[27] F. Safayeni, P. R. Duimering, K. Zheng, N. Derbentseva, C. Poile, and B. Ran, "Requirements engineering in new product development", Communications of the ACM, vol. 51(3), pp. 77-82, 2008.

[28] P. Shachaf, "Cultural diversity and information and communication technology impacts on global virtual teams: An exploratory study", Information \& Management, vol. 45(2), pp. 131-142, 2008.

[29] P. Shachaf, and N. Hara, "Team effectiveness in virtual environments: An ecological approach", New York: IGI Global, 2006.

[30] G. Suzanne, "Virtual teams, real benefits". Network World, vol. 18 (39), pp. 45, 2001.

[31] A. M. Townsend, S. M. DeMarie, and A. R. Hendrickson, "Virtual teams: Technology and the workplace of the future", The Academy of Management Executive, vol. 12(3), pp. 17-29, 1998.

[32] D. D. DuFrene and C. M. Lehman, "Managing virtual teams", Cambridge: Business Expert Press, 2015. 